\title{
Música e teatro de encômio na corte de D. João VI (1808-1821): um palco para louvar, divertir e instruir
}

\author{
Humberto Amorim (Universidade Federal do Rio de Janeiro, Rio de Janeiro, Rio de Janeiro, Brasil)
}

humberto.amorim@hotmail.com

\begin{abstract}
Resumo: O artigo analisa os papéis desempenhados pela música praticada nos teatros (e do próprio Teatro) no projeto de poder posto em prática no Brasil ao longo do período joanino (1808-1821), avaliando os aspectos simbólicos e práticos conferidos às manifestações artísticas neste ínterim. Para tanto, o texto suscita 33 anúncios recolhidos nos três periódicos inaugurais da imprensa brasileira (Gazeta do Rio de Janeiro, Idade d'Ouro e Correio Braziliense), articulando seus conteúdos com estudos referenciais sobre o tema (BUDASZ, 2008) e o conceito de "encômio alegórico" proposto por Teixeira (1999). Os resultados apontam para o uso da arte com uma tripla perspectiva: louvar, divertir e instruir.
\end{abstract}

Palavras-chaves: Música e teatro no Brasil do século XIX; Período joanino (1808-1821); Funções sociais da música; Arte de encômio alegórico; Anúncios musicais em jornais brasileiros; Inaugural imprensa brasileira.

Encomium music and theatre in the d. John VI court (1808-1821): A stage to praise, amuse and instruct

Abstract: The article analyzes the roles of music performed in the theaters in the power project carried out in Brazil during the Johannine period (1808-1821), evaluating the symbolic and practical aspects given to artistic manifestations in the first decades of the 19th century. To achieve this, the text presents 33 advertisements collected in the three inaugural journals of the Brazilian press (Gazeta do Rio de Janeiro, Idade d'Ouro and Correio Braziliense), articulating its contents with referential studies on the subject (BUDASZ, 2008) and with the concept of "encômio alegórico" proposed by Teixeira (1999). The results indicate the use of art with a triple perspective: praise, fun and instruction.

Keywords: Music and theater in the $19^{\text {th }}$ century in Brazil; Johannine period (1808-1821); Social functions of music; Panegyric art; Musical announcements in Brazilian newspapers; Inaugural Brazilian press.

Neste mesmo dia à noite se iluminou toda a Vila e as ruas se embelezaram com várias contradanças e coros de música, e por toda a parte se ouviam gritos de alegria - Viva o Nosso Príncipe Regente - Viva toda a Família Real (GAZETA DO RIO DE JANEIRO, 1816a).

No eixo luso-brasileiro, de modo geral, a arte cumpriu uma função sociocultural muito particular a partir de meados do século XVIII, quando mesmo os traços aparentemente mais líricos da produção árcade são revestidos por uma estética de louvor aos valores político-ideológicos cunhados pelos déspotas esclarecidos, representados, em Portugal, sobretudo pela figura do marquês de Pombal (1699-1782). Teixeira ${ }^{1}(1999)$ utiliza a expressão poesia de encômio alegórico para se referir a obras literárias setecentistas, especialmente de Basílio da Gama, nas quais laudatórios elogios não representavam apenas mera bajulice, mas antes vinculavam ideias e ideais aos conceitos de bem, justo e belo:

O predomínio de tais ideias [relação entre poesia e filosofia moral] no Setecentos favorecia a poesia como canto de louvor à virtude e aos virtuosos, o que se constitui numa espécie de incentivo teórico ao encômio versificado, entendido como a construção de um modelo da virtude civil, que erigia o bem como padrão desejável da ação política. Logo, o encômio setecentista não deve ser visto como simples exercício de bajulação, mas como consequência da utilidade civil da poesia. Essa é a feição dominante na produção do primeiro Arcadismo luso-brasileiro, do qual Basílio é expressão. Mesmo nos poemas tidos como mais líricos do período - como Marília de Dirceu, de Tomás Antônio Gonzaga, e Glaura, de Silva Alvarenga, por exemplo -, predomina essa visão arquetípica da poesia de louvor; variam sobretudo quanto à escolha da matéria: em vez de exaltar as virtudes cívicas, exaltam as virtudes do amor e dos aman- 
tes. De fato, nenhum desses livros adota o gênero lírico com a acepção pós-romântica de expressão de verdades singulares do indivíduo, mas entendem-no como elogio de ideias associadas ao bem, ao justo e ao belo. (1999, p. 260-261).

A dupla prerrogativa de estreitar os laços entre arte e política e apresentar a medida da beleza através de uma retórica moral de aspiração eterna é ainda mais evidente nas obras diretamente oferecidas a personagens políticos, em um movimento que atravessou o século e reverberou na produção artística - não apenas literária - das primeiras décadas do século XIX. Quando a comitiva de D. João VI desembarca no Brasil, em 1808, o entendimento do que deveria representar a arte para o Estado - seu mecenas por excelência - permanecia galgado nos mesmos valores. Naturalmente, a música apercebida pelos periódicos brasileiros em princípios dos Oitocentos não escapa à regra.

É possível sugerir, por isso, que o período joanino (1808-1821) represente o registro, no Brasil, do último grande impulso de uma arte oficial absolutista marcada pela predominância do encômio, das referências clássicas ao universo mítico greco-romano e das formas/gêneros/temáticas utilizadas pelos árcades, eventualmente pinceladas por um tom confessional e pré-romântico.

Tal percepção é ratificada pela análise dos três periódicos inaugurais da imprensa brasileira (Gazeta do Rio de Janeiro, Correio Braziliense, Idade d'Ouro), que nos dão fartas amostras do gênero. Já na primeira edição do Correio Braziliense, impresso em junho de 1808, reproduz-se um excerto que fora publicado na Gazeta de Londres no dia 14 de maio daquele ano e que apresentava o seguinte relato:

Ontem, certo número de [p. 79] Cavaleiros Portugueses, não menos distintos por seu
patriotismo que por sua graduação, se ajuntaram para celebrar com um esplêndido
jantar os anos de S.A.R, o Príncipe Regente; assim como a sua feliz chegada aos seus
Estados do Brasil. As saúdes principais foram: 'S.A.R. nosso amável Soberano e Prín-
cipe Regente. À Família Real. Que as ações dos Portugueses para com o seu Sobera-
no, correspondam aos fiéis sentimentos de seu coração. Aos nossos compatriotas, que
sofrem agora nas cadeias do despotismo Francês, desejando livrar-se para servirem
a seu Soberano. A memória de Pedro Alvarez Cabral, o descobridor do rico Império
do Brazil. Cantou-se hum hino composto pelo Presidente da Mesa J. A. Corrêa, com
a musica do ‘God Save the King'. Eu tenho toda a satisfação de ter obtido uma copia
deste hino, que o julgo tanto mais próprio, quanto é feliz a lembrança do autor em o
adaptar à música do canto Inglês God Save the King; porque esse mesmo pensamento
mostra a união que reina e deve reinar entre estas duas nações. [...] (CORREIO BRA-
ZILIENZE, 1808).

Em pontos chaves da narrativa, percebemos o quão a arte se inseria em um contexto marcado pelo irrestrito louvor ao reino e aos soberanos portugueses. Sob a égide do patriotismo, o jantar oferecido pelos distintos cavaleiros saudava o aniversário natalício de D. João VI (ritos de passagem), então príncipe regente, brindando também o restante da família real (personagens do presente), os presos pelo despotismo francês de Napoleão Bonaparte (atos heroicos) e a memória de Pedro Álvares Cabral (personagem histórico), denominado como "descobridor do rico Império do Brazil” (CORREIO BRAZILIENZE, 1808).

Composta por J. A. Corrêa, também a música cantada na ocasião se coaduna a este discurso legitimador e, não por acaso, foi batizada com o título de God Save the King [Deus salve o rei], uma paródia do célebre e homônimo hino inglês. É um contexto muito próximo ao apresentado pelo mesmo Correio Braziliense em abril de 1810, quando, durante um jantar, são oferecidos coros de música e "um pomposo Hino ao nosso amado Príncipe Regente, durante o qual toda a companhia se conservou em pé” (CORREIO BRAZILIENSE, 1810). 
A prática foi comum não somente em Portugal, mas também nas comunidades portuguesas espalhadas pela Europa e em suas colônias dispersas pela África, Ásia e América do Sul. No Brasil, alguns fatores fomentaram de modo especial a estética do louvor no início do século XIX:

(1) A chegada da família real portuguesa em 1808;

(2) O papel mais decisivo que o Estado passou a exercer na dinâmica cultural da colônia desde então, construindo teatros, importando artistas, criando corpos estáveis, encomendando obras etc.;

(3) Consequentemente, foi instituída - implícita e explicitamente - uma política de mecenato marcada pela lei da ação e reação: enquanto a mão direita do Estado ofertava, a esquerda se aprontava para receber, em forma de arte, a pretensa gratidão e amor de um povo submisso e fiel;

(4) Por fim, a criação da Imprensa Régia (1808), autorizando o funcionamento de tipografias e a circulação dos primeiros periódicos em território brasileiro, um passo decisivo para que o modelo artístico do encômio alegórico ganhasse ressonância no bojo sociocultural do período.

No Rio de Janeiro e na Bahia, numerosas incidências da arte de encômio alegórico são recorrentemente anotadas pelos pioneiros periódicos Idade d'Ouro (1811-1823) e Gazeta do Rio de Janeiro (1808-1822) ao longo da década de 1810. Tais ocorrências são inseridas nos mais diversos contextos e espaços socioculturais. Três exemplos recolhidos no jornal baiano - em meses próximos de um mesmo ano - ilustram tal fato com propriedade:

(1) Em janeiro de 1812, o aniversário de chegada da "Augusta Família” ao Brasil foi celebrado com um Te Deum no Colégio de S. Inácioº à época funcionando como Catedral da Bahia (IDADE D’OURO, 1812a);

(2) Pouco depois, o jornal informa que durante as comemorações do aniversário natalício da rainha D. Maria I, a Praça do Paço fora tomada "por uma tropa asseadíssima, que com a variedade de seus uniformes fazia à vista um admirável efeito; entre harmoniosos concertos de bandas colocadas em lugares convenientes” (IDADE D’OURO, 1812d).

(3) Meses mais tarde, a seção de avisos do jornal noticia que fora publicado o hino cantado "no Theatro de S. João da Bahia no dia 13 de maio de 1812, dia dos faustíssimos anos de S. A. R., o Príncipe Regente Nosso Senhor” (IDADE D’OURO, 1812e).

Observe-se como os exemplos permeiam as estruturas de quatro diferentes espaços sociais: a igreja, o palácio, a praça e o teatro. Em comum, a franca exaltação aos membros da realeza. Para melhor compreender as sinuosidades dos discursos, estratégias e táticas relativas à arte do encômio alegórico, cumpre destrinchar a lógica-guia que operava nas apresentações artísticas programadas nos principais teatros da América portuguesa de então.

\section{O teatro de encômio alegórico na corte de D. João VI}

De acordo com Scherpereel, “a música era uma das grandes paixões dos reis da dinastia de Bragança e foram despendidas somas consideráveis em sua honra” (1985, p. 13) . Durante sua permanência no Brasil (1808-1821), D. João VI não escapou à regra, fundando instituições e corpos culturais, cooptando artistas europeus e transformando-se no "mais importante mecenas com que contava o Rio de Janeiro” (PACHECO, 2007, p. 29).

Como parte de tais iniciativas, diversos teatros foram erigidos no Brasil após a chegada da família real (1808), com especial destaque para o Theatro de São João da Bahia (inaugurado em 13 de maio de 1812) e o homônimo Theatro de São João do Rio de Janeiro (inaugurado em 12 de outubro de 1813). Aliás, já nos espetáculos inaugurais deste último, 
a relação entre arte e financiamento estatal é reiterada pelo redator da Gazeta do Rio de Janeiro na seguinte passagem:

A iluminação exterior do teatro, ordenada com esquisito gosto, realçava o esplendor do espetáculo. Ela representava as letras J. P. R. alusivas ao Augusto Nome do PRÍNCIPE REGENTE NOSSO SENHOR, cuja Máo Liberal protege as Artes, como fontes perenes da riqueza e da civilização das Nações (GAZETA DO RIO DE JANEIRO, 1813, grifo nosso). ${ }^{4}$

Assim, com o expresso apoio do então príncipe regente, D. João VI, os teatros erigidos no Brasil começam a ocupar uma posição de maior destaque no ambiente sócio-político-cultural da colônia. E não somente pelo exercício das funções sociais que desempenhavam (sobre as quais discorreremos adiante), mas também pelo significativo aumento de verbas que suas administrações passaram a gerenciar após a chegada da família real. Somente a despesa dos cofres monárquicos com a manutenção da tribuna da Casa da Ópera, por exemplo, girava em torno de $100 \$ 000$ réis mensais em setembro de 1821, momento em que os teatros já não detinham os polpudos orçamentos da década anterior:

Tabela 1 - Despesa da Casa Real.

\begin{tabular}{|c|c|c|}
\hline-------- & Orçamento. & Despesa efetiva \\
\hline Mesadas Reais & $3.200 \$ 000$ & $3.200 \$ 000$ \\
\hline Tribuna na Casa da Ópera & $100 \$ 000$ & $\$$ \\
\hline
\end{tabular}

Fonte: GAZETA DO RIO DE JANEIRO, 1821a. ${ }^{5}$

Para se ter uma dimensão mais ampla do fato, basta debulhar o balanço publicado em três páginas completas do periódico Idade d'Ouro em março de 1814, como "conta resumida do que produziu e dispendeu o Theatro de S. João desta cidade [da Bahia]" (IDADE D’OURO, 1814a). Dele, depreendem-se algumas decisivas informações:

(1) A quantidade de récitas realizadas em 11 meses de atividades do teatro, o ínterim compreendido entre abril de 1813 e fevereiro de 1814, foi de 65 apresentações, sendo o mês de outubro/1813 o mais ativo (com 11 récitas) e o mês de julho/1813 o que apresentou o menor número de espetáculos (apenas um). Ou seja, em média, o teatro produziu cerca de seis apresentações mensais no referido interstício;

(2) A maior parte das receitas do teatro é detalhada a partir da venda de ingressos (plateia e camarote), sendo que os camarotes (7:191\$547 réis) renderam quase novecentos mil réis a mais do que os espaços da plateia (6:338\$135). As outras entradas se referem ao "Balanço a favor do Tesoureiro de Suprimentos" (2:665\$147) e o balanço "por débito total do Theatro incluindo 2:882\$792 que estão por pagar” (IDADE D’OURO, 1814a, p. 6). O total pecuniário, portanto, apontava a soma de voluptosos 19:077\$981 réis, uma quantia significativa para a realidade luso-brasileira de então. Vale destacar que, nesta prestação de contas, não foram declarados os valores referentes às loterias dirimidas pelo teatro com autorização real e cujos diversos sorteios foram descritos em edições anteriores/posteriores do mesmo periódico;

(3) No item de despesas, constata-se que os ordenados (que deveriam incluir pagamentos de funcionários e eventuais cachês de artistas convidados) somavam mais da metade dos gastos totais do teatro (cerca de 63\% dos custos, com 12:025\$927 réis). A orquestra e a 
música detinham o segundo maior orçamento fixo (cerca de 6,5\%, com 1:185\$060), o que demonstra que o Theatro já possuía um corpo musical estável desde sua fundação. Os valores empregados com pessoal incluíam também um corpo de dança, alfaiates, pintor e carpinteiros. Dos itens discriminados como gastos, aparecem tintas, madeiras, luzes, fazendas (itens variados) e "diversas despesas" (que, sem ser detalhadas, somavam quase 2 milhões de réis).

(4) Por fim, é intrigante observar que, diante de tantas receitas e despesas variáveis, o balanço do teatro tenha fechado a zero (com o valor de despesas literalmente igual ao de receitas, 19:077\$981 réis), em uma evidente demonstração ou de virtuosismo administrativo ou, mais provavelmente, de um sinuoso "jogo de cintura” para camuflar eventuais sobras positivas ou negativas no orçamento ${ }^{6}$.

No Theatro de São João do Rio de Janeiro, a perspectiva não foi diferente, inclusive com a administração das rendas e pagamentos gerando controvérsias desde a sua inauguração:

AVISOS. Havendo pessoas mal intencionadas que andam desacreditando a Administração do Real Theatro de S. João, o Proprietário faz público que abrindo este espetáculo no dia 12 de Outubro do ano passado [1813], pagou um mês adiantado à Companhia Cômica e de Dança, e que a 15 e 17 do corrente, pagou o terceiro mês que se venceu a 12, vindo por este modo a estar de contas justas com todas as pessoas que trabalham dentro dele, a saber Cômicos, Cantores, Dançarinos, Músicos, Pintores, Alfaiates, Comparsas, Carpinteiros e Porteiros, \&c (GAZETA DO RIO DE JANEIRO, 1814).

Naturalmente, a parte estatal dos investimentos tinha finalidades em nada fortuitas: entre 1808 e 1822, os teatros erigidos e/ou reformados estiveram dentre os espaços sociais mais utilizados para o exercício pleno do encômio alegórico. Analisando exclusivamente as programações narradas pela imprensa, pode-se sugerir que, em seus domínios, essencialmente se praticava uma arte de entretenimento oficializada.

Tais eventos laudatórios ocorriam tanto na programação oficial e/ou em celebrações relativas à Família Real quanto através de iniciativas particulares, como na ocasião em que três célebres músicos portugueses recém-chegados à Bahia celebraram o aniversário de "sua Majestade a Rainha Nossa Senhora” com o seguinte oferecimento:

BAHIA 13 de Dezembro [de 1811]. Rosa Fiorini Vaccani, Miguel Vaccani e João Olivetti, que sempre costumaram em Lisboa no Real Theatro de S. Carlos celebrar o aplausível Dia do Aniversário de SUA MAJESTADE A RAINHA NOSSA SENHORA, igualmente celebrarão este dia no Theatro da Bahia na noite de 17, onde cantarão diversas espécies de Música séria, semi-séria e bufa, oferecendo todos três o obséquio público não por interesse, mas sim por gratidão a uma Soberana Virtuosa e a uma Nação tão Respeitável (IDADE D’OURO, 1811a).

Uma semana depois, a crítica do concerto nos deixa saber que a apresentação fora precedida pela cerimônia do beija-mão no palácio do Governador Marcos de Noronha e Brito, o Conde dos Arcos, evento coordenado com uma grande parada na praça principal, iluminação das fortalezas e "descargas ao estilo" (IDADE D’OURO, 1811b). Pela noite, conde, oficiais, generais e "grande número de senhoras e pessoas graduadas" estiveram presentes ao concerto pelo aniversário da "Augusta Soberana tão Sábia como Virtuosa” (IDADE D'OURO, 1811b).

Começamos, assim, a visualizar uma cena do roteiro sobre o qual a música era articulada nas teias destes espaços oficiais, mostrando como, de certa forma, também o teatro se tornou uma extensão e/ou passagem entre acontecimentos ideologicamente concatenados e que encarnavam uma finalidade maior: espelhar, através da arte de encômio alegórico, a grandeza de seus soberanos. Ao comentar a peça $O$ Himeneu, apresentada em uma das diversas celebrações ocorridas na América portuguesa do casamento de D. Pedro e D. Maria 
Leopoldina, Malerba pontua com precisão o quão percuciente foi o espelhamento proposto - efetivo ou simbólico - entre membros da família real e personagens modelares contidos nos dramas apresentados:

Se nela dom Pedro e dona Leopoldina participam efetivamente - eles próprios ou atores que os representam - se eles 'falam', é direta a extensão da vida ao teatro. Não existe tal cisão entre uma e outra. A peça é sobre o acontecimento, sobre o vivido. O palco é contíguo ao paço, à capela, ao trono (apud BUDASZ, 2008, p. 181).

Os heróis do palco, portanto, são os mesmos que assistem ao espetáculo da tribuna, ainda que os personagens modelares das peças teatrais representadas sejam outros.

Antes de aprofundar este aspecto, contudo, é preciso esmiuçar a função mais aparente desempenhada pelo teatro, qual seja a de se converter em um espaço de recreio dignificado pelo caráter artístico das atividades que nele se realizavam. Em seus recintos, uma apresentação em noite de gala era revestida de solenidade e liturgia: vestidos pomposos, luminárias, vidros, retratos dos monarcas, autoridades, tribunas reais cheias e assim sucessivamente. Eram tais maneiras que, somadas à sua estrutura majestosa, conferiam legitimidade simbólica às dinâmicas socioculturais nele sacramentadas.

O teatro também era, ademais, um domínio de interação sobretudo para as elites, no qual predominava o aspecto social sobre o artístico. Vertido em ambiente de entretenimento, as suas grandes atrações não se restringiam ao que ocorria no palco. Ao contrário, o espetáculo era um acontecimento mais abrangente, com vários artifícios e camadas envolvidas (palco, plateia, tribunas, decoração, iluminação, números artísticos diversos, vestidos, sociabilidade, política etc.). Quando lançamos um olhar mais amplo sobre as práticas que envolviam uma eventual ida ao teatro, fica mais plausível compreender por que, por exemplo, um dos artefatos franceses mais comuns nas lojas de quinquilharias do período tenha sido justamente o "óculos de ópera"7.

A perspectiva de entreter e socializar, portanto, não se limitava à relação palco-plateia, embrenhando-se, inclusive, em outros espaços físicos dos próprios teatros:

Faz-se pública a nova Casa de Recreio no Salão do Theatro de S. João desta Cidade, denominada: O Jardim delicioso; sendo a sua abertura no dia 12 do corrente Outubro. Ali se hão de sair a toda e qualquer hora excelentes bebidas, tanto substanciais como espirituosas, e diversas iguarias a horas próprias: bem como porta franca a todos os jogos permitidos pelas Leis. Domingos Antonio Zuane, seu Proprietário, roga a todos os Senhores queiram frequentar a sobredita casa (IDADE D’OURO, 1814b).

Naturalmente, ambas as perspectivas - entreter e socializar - também deveriam ser atendidas pela programação artística levada a cabo. E, tanto para quem atuava quanto para quem assistia, a presença da realeza se convertia em condição sine qua non ao amplo roteiro de entretenimento traçado da manhã à madrugada (igreja - praça - palácio - teatro - rua). A grandeza do espetáculo se constituía, assim, na junção de diversos expedientes artificiosos. A ocasional falta de um deles era logo registrada pelos porta-vozes reais na imprensa:

[...] À noite iluminou-se a Cidade toda; e por complemento da solenidade de um dia que há de ser memorável nos Fastos da Monarquia, foi S. A. R. Servido Assistir à Ópera, onde se achou imensidade de Povo e pessoas d'ambos os sexos das mais distintas classes, que tanto concorreram para fazer aquele espetáculo o mais brilhante e aprazível; sendo somente minorado o regozijo público pela falta da Sereníssima Senhora Princesa Real, que por incomodo pessoal não pôde assistir à Representação e mais entretenimentos destinados para recreio de tão fausto dia. [...] (GAZETA DO RIO DE JANEIRO, 1821e, grifo nosso). 
Entretanto, é preciso destacar que as realizações artísticas que esmaltavam os sucessivos eventos de celebração à Família Real não cumpriam o mero papel de entretenimento, interação social e louvor, camadas mais superficiais do encômio alegórico. Antes, expressavam uma tácita função dogmática e moralizante cuja principal intenção era naturalizar a visão da realeza como portadora divina e definitiva da beleza, da justiça e do bem comum.

Neste sentido, os diversos gêneros artísticos que ocorriam nos teatros são, sem dúvida, os mais emblemáticos exemplos. Em seus domínios, as apresentações invariavelmente guardavam a tarefa didática de transformar o palco em uma pretensa "escola" dedicada à formação de súditos felizes e fiéis, conscientes da "grande graça" de partilhar as migalhas sobressaltadas da vida digna e sublime de seus soberanos.

Nesse processo, o teatro, especialmente o teatro em música, legitimado como escola de civilidade e indicador de civilização, passa a ser também um instrumento de propaganda política após a vinda da corte, celebrando aquele evento não como uma fuga, mas um ato heroico e intencional de difusão da civilização europeia através da recriação de um império na América. Obras como Ulisseia, Triunfo da América e o Juramento dos Numes, abundam em referências às epopeias de Ulisses, que cruza os mares para fundar Lisboa (Ulissipo), civilizando os bárbaros locais, e de Enéas, o troiano que também conduz através dos mares a semente da civilização para fundar no Lácio o império romano. A relação entre esses heróis e os soberanos portugueses já era feita desde os tempos de dom Manuel, pois o rei simbolizava a nação portuguesa que singrava os mares levando a civilização europeia aos bárbaros de três continentes. Mas dom João VI seria o primeiro rei europeu que, assim como Enéas, atravessaria os mares para fundar um novo império, e, como Alexandre, trocaria a segurança de sua corte e seu lar para reinar nos confins do mundo (BUDASZ, 2008, p. 181).

A crônica publicada no Idade d'Ouro de 13 de outubro de 1813 corrobora tal perspectiva e toma o aniversário do então "sereníssimo Príncipe da Beira” (D. Pedro de Alcântara, futuro D. Pedro I) como pano de fundo para desvelar o quão o agudo caráter doutrinador da arte de encômio alegórico não passou desapercebido nem às autoridades portuguesas da época e nem à imprensa brasileira que representava as suas vozes:

A escolha da peça não podia ser melhor lembrada, nem melhor acomodada às circunstâncias do Dia. O Theatro deve ser a escola onde se forme o espírito Nacional; e onde se estudem não só as virtudes particulares, como as virtudes estrondosas que fazem os Heróis e que imortalizam as Nações. O Theatro é um termômetro exato para calcular o espírito de uma Nação; e as peças que nele se representam são ordinariamente o espelho, na reflexão de cujos raios se divisam os semblantes dos Espectadores. [...]

É portanto um objeto digno da mais escrupulosa vigilância do Governo a escolha dos dramas, que servem de divertir e instruir o Público. E que melhor escolha se pode fazer neste gênero que a dos Heróis da Pátria, a cujos feitos devemos a nossa atual subsistência e grandeza aos olhos das Nações? E quem é mais digno do que Vasco da Gama para se expôr aos olhos dos Portugueses, como modelo de constância, sofrimento e lealdade. Tal foi a comédia que fez o recreio Público e que despertou memórias de saudade nos corações Portugueses na noite deste Dia em tudo grande. Nela viram os Espectadores a fidelidade Portuguesa, o amor da glória e a indústria maritima, tudo levado sobre ponto [...] (IDADE D'OURO, 1813).

Fica expresso em que medida o Teatro cumpria a tripla estratégia política do encômio alegórico: louvar, divertir e instruir. Três bases operando em sintonia, em uma taciturna sobreposição que camufla e suaviza os propósitos da camada mais profunda (a instrução) sob o efeito imediato das mais superficiais (a diversão e a louvação). No exemplo, as "mil aclamações e vivos sinais de alegrias" demonstrados pelo público configuram um ambiente perfeito para que a mensagem formativa alcance mentes e corações abertos. O "recreio público", assim, jamais foi gratuito. Seu objetivo era o de moldar o espírito popular em direção às "virtudes estrondosas" e ao exercimento de uma submissa fidelidade à nação. A proposi- 
ção, inclusive, opera em duas diferentes vias na narrativa:

Primeiramente, na exaltação da pátria portuguesa, que se efetiva ora através da rememoração de figuras históricas como Vasco da Gama, tomado como herói modelar e espelho imediato dos soberanos atuais; ora pela remissão aos valores da navegação mercantilista - "a indústria marítima" -, que sugava do Brasil as matérias-primas responsáveis por sustentar a balança comercial de Portugal em tempos de guerra;

Depois, na exaltação aos membros da família real. Para sustentar a narrativa conformadora diante dos colonizados, não bastava reviver a glória dos feitos passados ou de personagens mortos ("espíritos da Nação”), mas também referendar continuamente as teias vivas da engrenagem. Deste modo, o encômio alegórico não se limitava a fazer com que os soberanos refletissem a grandeza dos heróis passados, mas transformava cada gesto, movimento ou ação do teatro em um artifício de louvor à realeza, o que, em síntese, configura-se em uma peremptória ação-tentativa de permanentemente colocar os membros da família real acima do bem e do mal, revestindo o seu poder de uma aura sagrada e intocável.

Como consequência, as atividades musicais engendradas no espaço teatral são desprovidas de qualquer caráter crítico ou transformador: "mesmo relacionado ao poder e às decisões políticas, o teatro não era um espaço de debate, mas de aclamação pública da decisão do soberano" (BUDASZ, 2008, p. 182). Antes, tais manifestações artísticas operavam no status quo, nutrindo-se dele à mesma proporção em que o nutria. Mantendo o patamar de objeto digno "da mais escrupulosa vigilância do Governo", podemos sugerir que esta categoria de música, teatro, dança e poesia converteu-se em ferramenta sistêmica que embaçava a percepção da realidade enquanto paralelamente embotava gargalhadas e lágrimas.

É possível visualizar as funções específicas do teatro de forma mais cristalina ao resgatar o relato das comemorações do aniversário de Dom Pedro de Alcântara, em 1814. Comparada ao ano anterior, observa-se uma completa reiteração de padrões: são as mesmas ocasiões (captadas em anos sucessivos), relativas ao mesmo personagem, publicadas no mesmo periódico e redigidas pelo mesmo redator. Nos diversos números teatrais apresentados, novamente sobressaem as três perspectivas indissociáveis: diversão, instrução e louvor.

À noite concorreu no Theatro um luzido e numeroso concurso; o qual penetrado da mais viva alegria e respeitoso acatamento esteve em pé diante do Retrato do Sereníssimo Senhor Príncipe da Beira, que ali apareceu em uma nuvem de artificio ao som de harmoniosos Hinos, que foram precedidos de um Elogio Dramático; no qual se pintou a saudade chorando nos frescos bosques de Cintra, e congratulando o Brazil pela posse de um Príncipe que é as Esperanças e Delícias da Nação.

Depois desta engenhosa abertura, que excitou nos circunstantes as mais doces comoções, representou-se a primeira parte da Peça intitulada: Pedro Grande ${ }^{8}$, a qual quadrava com a maior propriedade ao Augusto assunto do dia, não só pela circunstância do Nome, como pela natureza do enredo; o qual consiste em representar aquele Modelo dos Soberanos viajando pelos Reinos estranhos, para aprender as Artes que geram a comodidade e a riqueza; e para promover a prosperidade da Nação, que ainda chora por ele; da Nação, que nos nossos dias acaba de concorrer com tanto brio para a paz e felicidade do Mundo.

Os votos do Brazil inteiro, e particularmente desta Cidade, estão perenemente ao pé do Trono Eterno para que o Céu prospere os Preciosos Dias do Augusto Sucessor da Monarquia (IDADE D’OURO, 1814c).

O roteiro dos eventos ocorridos no teatro é basicamente o mesmo do ano anterior, assim como os papéis e espaços ocupados pela arte. Para entreter o "numeroso concurso", a programação artística tinha forte caráter dogmático, formativo e moralizante: na música, os sons de harmoniosos hinos abriam alas para que uma "nuvem de artifício" materializasse a 
presença do príncipe a partir de um retrato de sua figura exposto no palco. Elogios dramáticos, comédias e peças sobre personagens heroicos e históricos costuravam a trama, eventualmente entremeada por recitação de poesias e números de dança (menos frequentes) ${ }^{9}$.

Intrigante observar como o vulto fantasmagórico do homenageado - teoricamente ausente - é, na verdade, a maior presença física da festa. Para Budasz, "mesmo estando no camarote e sendo substituído no palco por um quadro ou imagem, o monarca representa a si próprio" (2008, p. 182). Portanto, tais eventos representavam, antes de tudo, um espetáculo do rei (e não somente para o rei).

A par do entretenimento, também fica nítido como a dimensão “educadora” desempenhada pelo teatro ia muito além da mera escolha do drama ou comédia que iria ser representada. Embora, na maioria dos casos, tais obras encarnassem propositadamente um enredo que resgatava alegoricamente personagens históricos do passado (Vasco da Gama, Pedro Álvares Cabral, duque de Borgonha etc.), projetando-os como figuras modelares, espíritos da Nação e reflexos imediatos das virtudes da realeza, por vezes as temáticas profanas eram mais livres, conforme podemos constatar nas obras seculares de Marcos Portugal apresentadas nos palcos dos teatros e palácios da Corte.

Assim, não era somente o enredo das peças que definia a essência do teatro de encômio, mas os diversos artifícios de louvor dedicados aos membros da família real durante as apresentações. Em 1819, as celebrações do aniversário natalício da princesa real nos dão a medida exata da conjectura:

Estava o Theatro rica e profusamente iluminado com globos e mangas de vidros de diferentes grandezas e variadas formas, e era brilhantíssimo o concurso de pessoas distintas vestidas em grande gala, com a maior elegância e riqueza. Logo que Apareceram Sua Majestade e Altezas Reais, se deram unânimes Vivas a EL-REI Nosso Senhor, repetidos com exaltado entusiasmo. Recitou-se um elogio alegórico acompanhado de música e ornado com as efígies de SS. MM. e de SS. AA. RR. o Príncipe e Princesa Real. Seguiu-se a Ópera séria intitulada Caçada de Henrique IV, música excelente da composição do celebre Puccita. No fim do $1^{\circ}$ Ato se desempenhou um Balé Sério Pantomimo intitulado Ulysses e Penelope, da composição de Augusto Toussaine, Primeiro Dançarino do mesmo Theatro; rematando o divertimento com o $2^{\circ}$ Ato da Peça (GAZETA DO RIO DE JANEIRO, 1819) ${ }^{10}$.

Globos e filetes de vidros de variados tamanhos e formas, vestidos de gala, gritos exaltados de "vivas", elogios alegóricos, exposição de retratos e, em meio a tudo isso, óperas, números musicais e balés. Portanto, o ambiente não era propriamente o da arte, mas o do artifício. E tal realidade foi soberana, pelo menos no que tange às apresentações assistidas pelos e/ou dedicadas aos membros da família real, que basicamente representaram o substrato dos eventos teatrais narrados pela inaugural imprensa brasileira no período joanino (1808-1821).

É importante destacar como tal modelo teatral (que, como vimos, refletia um roteiro de encômio mais amplo) não se limitou aos palcos do Rio de Janeiro. Na Bahia, ao longo da década de 1810, já apresentamos diversas incidências recolhidas no periódico Idade d’Ouro indicando como a capitania refletia imediatamente os acontecimentos relativos à família real que chegavam à região através dos navios.

Talvez o exemplo mais nítido tenha sido o ocorrido em maio de 1819, quando o Senado da Câmara, logo após receber da Corte do Rio de Janeiro “a agradabilíssima notícia do próspero parto da Sereníssima Princesa Real, logo ordenou que se iluminasse a Cidade por três noites sucessivas; e dispôs-se com pressuroso fervor a render as Graças ao Altíssimo em uma Festividade Sagrada” (IDADE D’OURO, 1819). Na ocasião, houve um "luzido arruma- 
mento" das Tropas da Guarnição no Terreiro de Jesus, missa solene e Te Deum com grande música, além de, pela noite, "teatro com imenso concurso e evidentes sinais de regozijo público pelo Nascimento da Augusta Herdeira do Trono, que é firmado sobre os corações do povo fiel que o adora" (IDADE D’OURO, 1819).

Mesmo que não tenha havido circulação de periódicos próprios em outras capitanias nas duas primeiras décadas do século XIX, alguns relatos sobreviveram indiretamente em notas publicadas na Gazeta do Rio de Janeiro. Já em fevereiro de 1809, por exemplo, eventos ocorridos no Theatro da Vila, de Porto Alegre, em celebração à "Restauração de Portugal” são narrados nas páginas do porta-voz informal da Corte:

Logo que o Excelentíssimo Governador do Rio Grande de S. Pedro soube da faustíssima Restauração de Portugal, a fez anunciar com a maior pompa no dia 02 de Fevereiro pelo Senado da Câmera da Vila de Porto Alegre, precedido de um bando e acompanhado por uma escolta de Cavalaria e numerosa música.

No dia 06, principiou um Tríduo na Igreja Matriz, havendo Missa cantada, Exposição do Santíssimo, Sermão e no terceiro dia da tarde Te Deum e Procissão [Igreja], que passou por entre duas alas de Tropa Miliciana, indo na retaguarda a Tropa de Linha [regimentos militares] com o Excelentíssimo Governador e imenso Povo. [...]

Em as noites de 8, 9 e 10 houve uma brilhante iluminação em toda a Vila, distinguindo-se a Casa da Câmera [palácios ou espaços oficiais] com o prospecto de um jardim, sustentado por 12 colunas regulares com vários dísticos e, no mais alto da perspectiva, o Retrato do PRÍNCIPE Regente N. S. [Família Real], que se fez patente na primeira noite com assistência do Excelentíssimo Governador, Corpo Militar, Nobreza e muito Povo, rompendo ao mesmo tempo a música, o fogo do ar e gritando todos: Viva o Nosso Augusto PRINCIPE, Viva a Casa de Bragança.

A esta iluminação seguiram-se no Theatro público da dita Vila duas noites de Ópera gratuita [Teatro]; a primeira pelo Excelentíssimo Governador, e a segunda pela Câmera, estando também o teatro iluminado. Além disto houve mais três dias de luminárias e máscaras, desde o dia 2 ate 14 de fevereiro. [ruas]

Não é para maravilhar que causasse prazer a Restauração da Pátria a uma Capitania que tanto a sabe se defender neste Continente e que em todos os tempos se tem mostrado benemérita do Soberano, e de muitos modos [parágrafo final sintetizando o propósito do encômio alegórico]. (GAZETA DO RIO DE JANEIRO, 1809, grifo nosso).

É a expressão didática do prevalecente roteiro das festividades de encômio: igreja, praça, palácio, teatro, ruas - onde, guardadas as devidas particularidades e liturgias, cada ambiente se torna uma extensão do anterior e uma mediação para os acontecimentos do próximo. Diante do cenário mais amplo, fica possível compreender sob quais baluartes operavam as programações artísticas levadas a cabo nos teatros das vilas de diferentes capitanias.

Em Vila Rica, capitania de Minas Gerais, encontramos mais um exemplo do gênero por ocasião da elevação do Estado do Brasil à condição de Reino Unido de Portugal, Brasil e Algarves. Ocorridas em janeiro de 1816, as celebrações na localidade incluíram iluminações por três dias (12, 13 e 14 de janeiro), missa de ação de graças na Capela de Nossa Senhora do Carmo, “Ópera gratuita no Theatro da referida Vila”, designação de uma pessoa da governança para ir à Corte beijar a mão do rei, além de "diversas partidas de música” protagonizadas tanto pelos "regimentos" quanto pelos "paisanos desta vila, vagando pelas ruas dela e alternando-se com amiudado fogo do ar e repetidos vivas e aclamações ao Augusto Nome de S. A. R. que tanto se empenha no bem geral de seus vassalos" (GAZETA DO RIO DE JANEIRO, 1816b).

Este último exemplo é particularmente determinante por desvelar como o modelo de encômio alegórico e o seu respectivo discurso narrativo na imprensa atravessaram distintos momentos políticos nas primeiras décadas do Brasil oitocentista. Eles foram estabele- 
cidos sobretudo após a chegada da família real portuguesa (1808); alargaram-se por todas as capitanias até que o colonial Estado do Brasil fosse elevado à categoria de Reino Unido com Portugal e Algarves (1815); e finalmente perduraram nos anos subsequentes, permanecendo ativos mesmo após a Proclamação da Independência (1822), conforme atestam diversas notas recolhidas nos periódicos do período:

Vila de S. Salvador. Exmo. Senhor - A Câmara desta Vila tem a honra de felicitar a Sua Majestade Imperial, o Senhor D. Pedro I, por ser elevado ao Trono cuja Aclamação se verificou no dia doze deste mês por todos os habitantes deste País com o maior entusiasmo [...].

Ilmo. e Exmo. Senhor. - Havendo eu anunciado a V. Ex. que logo que me fosse possível lhe faria uma fiel narração dos Festejos que tiveram lugar nesta Vila pela Feliz Aclamação de Sua Majestade Imperial, julgo do meu dever não deferir para mais longe esta obrigação, para que V. Ex. conheça até que ponto chega o patriotismo dos fiéis e honrados Campistas [moradores da Vila de São Salvador dos Campos dos Goitacazes] e o quanto amam e adoram o Nosso Herói, o Nosso Idolatrado Imperador.

Anoiteceu o dia 11 de Outubro: apareceram todas as casas da Vila Iluminadas; celebraram-se solenes matinas na Igreja Matriz: no dia seguinte (sempre memorável) celebrou-se Missa cantada do Espírito Santo com uma soberba Oração análoga ao dia e às circunstâncias feita pelo Padre Domingos Ribeiro; havendo assistido a estes solenes atos a Câmara, o Clero, a Nobreza, Militares, e o Povo. [...]

Depois de feita assim a Aclamação com toda a unanimidade de sentimentos, com a maior alegria e ordem fomos para a Matriz assistir a um solene Te Deum em ação de graças ao Todo Poderoso por tão alto benefício, findo o qual tornamos para a Praça e se deram as descargas de alegria, que foram entrelaçadas de artilharia. Isto acabado, dei eu os Vivas à Nossa Santa Religião, à Independência do Brasil, à Assembleia Geral Constituinte do Brasil, ao Imperador Constitucional do Brasil, o Senhor D. Pedro I, à Imperatriz e à Dinastia de Bragança Imperante no Brasil e ao Povo Brasileiro, que foram respondidos pelos espectadores com o maior entusiasmo. À noite houve ópera grátis. O Theatro estava ricamente iluminado interior e exteriormente: os camarotes estavam dignamente ocupados: não se viam senão ornados, plumas, vestidos bordados de ouro e prata, muitas fardas; e a plateia estava cheia de luzida gente.

Logo que corri as cortinas ao meu camarote e apenas dei os Vivas foram imediatamente respondidos com aplauso geral e todo o entusiasmo: rompeu a orquestra uma excelente sinfonia, seguindo-se um Drama aqui composto, que tinha por título $\boldsymbol{O}$ Triunfo do Brasil, que fora representado por pessoas gradas do País, aparecendo no fim deste o Busto do Nosso Adorado Imperador, que tinha por baixo esta inscrição: Eis Pedro do Brasil o Defensor, D’Áureo Império Primeiro Fundador.

A cuja aparição rompeu logo a Música um Hino Brasileiro composto pelo Padre Mestre Fr. Antonio de Santo Elias, e a cuja vista parece que ao som das palmas e dos Vivas se desfazia o Theatro; repetindo-se nessa ocasião várias Odes e Sonetos, por mim, pelo Reverendo Vigário da Vara, pelo Padre José Rodrigues, e outras pessoas, representando-se depois pela Companhia do Theatro a Peça José Segundo, que fora bem executada, terminando o espetáculo às duas horas da noite. [...]

No dia 13 e 14 também houve ópera; nos dias 15 e 16 apareceram galantes máscaras e várias danças em diferentes caracteres, bem arranjadas e luzidas: nas tardes dos dias 17 e 18 houve excelentes cavalhadas, figurando combates entre Mouros e Cristãos, feitas por pessoas limpas do País debaixo da direção do Capitão Antonio Desiderio, continuando nestes mesmos dias máscaras e danças: no dia 19 por ser o Dia do Nome de Sua Majestade Imperial, houve festa de Igreja e Procissão pelas ruas principais da Vila, que foi seguida do mais luzido acompanhamento; nessa noite houve ópera e no dia 20, apesar da chuva, houve um excelente fogo de vistas [...].

Agora só me resta pedir a V. Ex. a desculpa que mereço por lhe ter apresentado uma narração enfadonha e tosca, pela rasteira frase em que é feita, mas sincera e fiel, rogando ao mesmo tempo a V. Ex. a honra de fazer chegar, sendo assim do seu agrado, aos Pés de Sua Majestade Imperial; enquanto eu com todo o respeito protesto que sou. - Ilmo. e Exmo. Senhor José Bonifacio de Andrada e Silva. - De V. Ex. o mais humilde criado José Manoel de Moraes. Villa de S. Salvador 22 de outubro de 1822 (GAZETA DO RIO DE JANEIRO, 1822b, grifo nosso). 
Em localidades diversas, outros festejos do gênero são relatados na imprensa após 1822, indicando que o movimento também não fora isolado e/ou centralizado após a Independência. Na Vila do Sabará, capitania de Minas Gerais, houve celebrações pela aclamação de D. Pedro I como imperador do Brasil com as mesmas reiteradas ações da igreja nos templos, dos regimentos nas praças, das autoridades em palácios/espaços oficiais e do povo nas ruas, além, naturalmente, dos espetáculos ocorridos em teatros. Sobre estes últimos, o redator professa:

[...] não faltou a ela [ópera] alguns dos que sabem conhecer, que a cena é um ato público onde se representam máximas da Política, da Moral, do amor da Pátria, do valor, do zelo e da fidelidade, muito principalmente quando esse entretenimento é positivo a demonstração de alguma ação memorável, como a que se aludia. Na abertura do Theatro apareceu o Retrato de S.M.I e pondo-se logo todos de pé gritou do seu camarote o Desembargador Ouvidor os mesmos antecedentes Vivas e o Povo com tanta reverência como alegria gostosamente lhe respondia (GAZETA DO RIO DE JANEIRO, 1822c, grifo nosso).

Política e teatro em carne e unha. Neste sentido, Budasz aponta que "a estreita relação entre poder monárquico e teatro, mais especificamente a ópera, ajuda a explicar o vácuo deixado pela abdicação de dom Pedro I em 1831" (2008, p. 182) ${ }^{11}$. Podemos inferir, portanto, que a perspectiva de divertir, instruir e louvar também regeu a relação do reinado de D. Pedro I com as manifestações teatrais ao longo da década de 1820, uma herança do modelo de encômio estabelecido no Brasil sobretudo por seu pai, D. João VI, na década de 1810.

O fato é corroborado por documentos coetâneos. Um deles foi a missiva destinada ao imperador, em julho de 1825, por Fernando José de Almeida (conhecido à época como "Fernandinho"). Na carta, o então proprietário do Teatro São Pedro de Alcântara não somente solicitava permissão para rodar loterias visando a reconstrução da casa, acometida por um incêndio em 1825, mas justificava sua intenção com um alerta ao soberano para as capacidades do teatro em entreter, instruir e distrair a população de possíveis ajuntamentos, propícios e potenciais sobretudo em "tempos de efervescência".

Vossa Majestade Imperial melhor do que o suplicante conhece que as nações civilizadas por um manejo de estudada política, deram um grande estudo a alimentar e aperfeiçoar toda sorte de espetáculos como um meio, não só de instruir e entreter o povo, mas até de distraí-lo de outros ajuntamentos, e isto principalmente em tempos de efervescência, nos quais é de sabedoria desviar docemente as paixões com tanta maior destreza quanto menos se pressentir o plano da direção que se lhe dá (apud BUDASZ, 2008, p. 182).

Enquanto espaço sócio-político-cultural, a apelação de Fernandinho resume a principal função desempenhada pelo teatro brasileiro (e, por conseguinte, pela música nele performada) nas três primeiras décadas do Brasil oitocentista: promover uma rede de entretenimento, louvor e instrução com a finalidade específica de obnubilar paixões, conformá-las ao gosto suave do encômio, conduzir ideologicamente sem deixar que se pressinta "o plano da direção que se lhe dá”.

Em síntese, na luta pela apreensão do imaginário coletivo, os teatros ofereciam aos espectadores (e mesmo aos que não frequentavam os seus domínios) a ilusão de partilhar uma graça Real que, todavia, não lhes pertencia, a não ser pela eventual benevolência de seus soberanos que, vez ou outra, abriam as portas das "óperas grátis" para que o grande espetáculo do rei, nunca ausente, pudesse se cumprir sobre todos. 
Com o exposto no artigo, torna-se mais plausível situar o teatro no roteiro de encômio alegórico sobre o qual se articulava a música praticada em corporações e espaços sócio-político-culturais cooptados pelo Estado:

Tabela 2 - Espaços e funções sociais da música de encômio alegórico nas primeiras décadas do Brasil oitocentista.

\begin{tabular}{|c|c|c|c|c|}
\hline Categoria & Lugar/Espaço & Corpo Social & Prática/Repertório & Funções \\
\hline $\begin{array}{c}\text { Música } \\
\text { religiosa }\end{array}$ & $\begin{array}{c}\text { Catedrais, igrejas, } \\
\text { templos, colégios } \\
\text { religiosos }\end{array}$ & $\begin{array}{c}\text { Sacerdotes, mú- } \\
\text { sicos contratados } \\
\text { (de corpos está- } \\
\text { veis ou não) }\end{array}$ & $\begin{array}{c}\text { Missas cantadas, Te } \\
\text { Deum Laudamus, } \\
\text { vésperas, ofícios, } \\
\text { matinas etc. }\end{array}$ & $\begin{array}{c}\text { Louvor, } \\
\text { ação de graças, } \\
\text { legitimação } \\
\text { simbólica }\end{array}$ \\
\hline $\begin{array}{c}\text { Música dos } \\
\text { regimentos } \\
\text { militares }\end{array}$ & $\begin{array}{c}\text { Praças, passeios } \\
\text { públicos, } \\
\text { coretos etc. }\end{array}$ & $\begin{array}{c}\text { Regimentos } \\
\text { militares, tropas } \\
\text { de guarnição }\end{array}$ & $\begin{array}{c}\text { Bandas de música, } \\
\text { repertório festivo }\end{array}$ & $\begin{array}{c}\text { Entretenimento, } \\
\text { mediação de } \\
\text { espaços }\end{array}$ \\
\hline palaciana & $\begin{array}{c}\text { Palácios, câmara, } \\
\text { senado, casa da } \\
\text { relação etc. }\end{array}$ & $\begin{array}{c}\text { Membros da } \\
\text { realeza, seus } \\
\text { representantes, } \\
\text { autoridades, etc. }\end{array}$ & $\begin{array}{c}\text { Saraus, recepções, } \\
\text { bailes, cerimônias do } \\
\text { beija-mão, ensaios } \\
\text { etc. }\end{array}$ & $\begin{array}{c}\text { Obnubilação, } \\
\text { diversão, } \\
\text { criação de um } \\
\text { imaginário } \\
\text { coletivo }\end{array}$ \\
\hline Música teatral & $\begin{array}{c}\text { Teatros, casas de } \\
\text { ópera }\end{array}$ & $\begin{array}{c}\text { Orquestras, solis- } \\
\text { tas, grupos de } \\
\text { câmera, corpos } \\
\text { estáveis do teatro }\end{array}$ & $\begin{array}{c}\text { Dramas com música, } \\
\text { hinos encomiásticos, } \\
\text { hinos patrióticos, } \\
\text { óperas etc. }\end{array}$ & $\begin{array}{c}\text { Divertir, ins- } \\
\text { iduir, conduzir } \\
\text { ideologicamente, } \\
\text { desviar, distrair }\end{array}$ \\
\hline
\end{tabular}

É preciso ressaltar que a programação teatral narrada pela imprensa, sobretudo a operística, foi aquela que guardava relação estreita com acontecimentos, políticos ou sociais, relativos à família real portuguesa. Grande parte das apresentações promovidas pelos teatros da época serviam irremediavelmente a tal propósito, mas há exceções. Como vimos, só o Teatro de S. João da Bahia promoveu 65 récitas entre abril de 1813 e fevereiro de 1814. No Rio de Janeiro não foi diferente e uma parcela destas dezenas de eventos escapava ao mero propósito de servir à realeza, como, por exemplo, ocorreu com alguns dos "benefícios" promovidos em nome de um ou vários artistas, ocasiões em que parte substancial da renda (afora os pagamentos dos custos) era dedicada aos que protagonizavam os espetáculos juntamente com os seus convidados.

Neste contexto, eventualmente peças de caráter "mais artístico" do que instrutivo também alcançaram os palcos, proporcionando estreias, no Brasil, de óperas de autores como Rossini ${ }^{12}$ e Mozart ainda antes da Proclamação da Independência (1822):

Segunda feira 17 do corrente a benefício de Paulo Rosquellas, se há de representar o excelente novo Drama jocoserio em música intitulado D. João ou o Convidado de Pedra [Don Giovanni]. Esta Peça é uma dos chefes d'obra do célebre Mozart, tendo sido representada em todas as Capitais da Europa com geral aceitação, não só pela grande música de que é composta, como pelas interessantes Cenas de que é adornada, diversificando em algumas daquelas que se tem representado no idioma Português: finalizando o primeiro Ato com um dançado de máscaras e o segundo com a Cena do inferno, onde se vê $D$. João Tenorio castigado e submergido pelas fúrias com uma chuva de fogo: seguindo-se a dança o Recrutamento na Aldeia, finalizando o divertimento o segundo Ato da Peça. (GAZETA DO RIO DE JANEIRO, 1820g, grifo nosso) ${ }^{13}$. 
É de se lamentar que, por um lado, a cooptação do teatro e de seus artistas pela monarquia portuguesa não tenha permitido a consolidação de um espaço sociocultural mais livre para apresentações do gênero nas primeiras décadas oitocentistas (o que paulatinamente iria começar a mudar a partir da década de 1830); por outro, que o modelo narrativo da imprensa, também um braço serviçal do Estado, não tenha conferido a mesma atenção descritiva aos eventos que escapavam às meras odes para com os membros da realeza. São fatos que cercearam não somente a programação mais ostensiva de obras de artistas estrangeiros e luso-brasileiros desvinculados do poder real, mas que também limitaram tematicamente parte substantiva da produção de importantes artistas radicados ou nascidos no Brasil, como aconteceu com Marcos Portugal e Pe. José Maurício Nunes Garcia.

\section{Notas}

1 Ivan Teixeira (1950-2013) foi professor livre-docente da USP e professor titular de Literatura Brasileira na Universidade do Texas. Seu livro Mecenato Pombalino e Poesia Neoclássica (1999), no qual esmiuça o conceito de poesia de encômio alegórico, foi agraciado com o Prêmio Jabuti e o Lasa Book Prize no ano de 2000. Escreveu quatro livros e publicou mais de 150 artigos, tornando-se um dos críticos e ensaístas literários mais reconhecidos do Brasil na passagem entre os séculos XX e XXI.

2 Na ocasião, houve uma forte chuva cujos raios provocaram duas mortes em uma casa de dois andares, além do desabamento de pedras e a quebra de uma vidraça no templo onde ocorria o evento, fato que ocorreu justamente quando se oficiava o Te Deum: "O terror e a desordem foram tais neste momento que interrompendo o acto, sobravam a motivar as mais funestas consequências” (IDADE D’OURO, 1812b). Uma semana depois, o Idade d'Ouro volta a reverberar o ocorrido: "O Excelentíssimo e Reverendíssimo Prelado com piedoso reconhecimento à especial Mercê [graça] que nos fez o Altíssimo, preservando dos estragos do raio que caiu no Colégio no dia 23 o numeroso povo que havia ali concorrido por motivo tão respeitável, fez ontem celebrar no mesmo Templo Te Deum em ação de graças, com assistência de toda a Nobreza desta Cidade” (IDADE D’OURO, 1812c).

3 Para corroborar sua hipótese, o autor pondera que "basta recordar a riquíssima biblioteca musical reunida por D. João IV, ele mesmo compositor e crítico de mérito, a contratação de Domenico Scarlatti sob o reinado de D. João V, a de David Perez e dos maiores cantores italianos sob D. José I, sem esquecer a construção do faustoso teatro de ópera ‘dos Paços da Ribeira' ou ‘Ópera do Tejo', considerado por Burney como o teatro mais brilhante de toda a Europa, infelizmente destruído no ano de sua inauguração pelo grande terremoto de 1755” (SCHERPEREEL, 1985, p. 13).

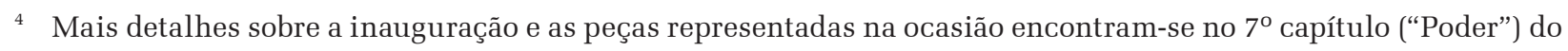
livro de Rogério Budasz: Teatro e Música na América Portuguesa (2008, p. 153-180).

5 Os valores foram repetidos nos quatro meses seguintes: outubro (GAZETA DO RIO DE JANEIRO, 1821b), novembro (GAZETA DO RIO DE JANEIRO, 1821c), dezembro de 1821 (GAZETA DO RIO DE JANEIRO, 1821d) e janeiro de 1822 (GAZETA DO RIO DE JANEIRO, 1822a). Neste último exemplo, além das mesadas reais e os gastos com a tribuna, também é descrito um valor de 1.674\$560 réis referente à “obra na antiga casa da ópera para aquartelamento da Tropa” (GAZETA DO RIO DE JANEIRO, 1822a).

${ }^{6}$ O mesmo ocorre na prestação de contas do Theatro referente ao ano de 1815, quando novamente as despesas igualam as receitas, porém tendo como denominador comum uma soma pecuniária significativamente menor: 7:693\$012 réis (IDADE D’OURO, 1816). No balanço de 1818, publicado em março de 1819, a igualdade entre entradas e gastos volta a acontecer: 6:513\$240 réis. A par da "coincidência”, destaque-se como, ao longo da década de 1810, houve uma paulatina redução (2/3) do orçamento do Theatro de S. João.

7 "Mr. Maullaz, novamente chegado de Paris, morador na rua Direita, N. ${ }^{\circ}$ 28, tem um grande sortimento de diversas mercadorias de França, como [...] óculos de ópera [...] \&c. tudo do melhor gosto e pelos preços mais cômodos” (GAZETA DO RIO DE JANEIRO, 1817, grifo nosso).

${ }^{8}$ A temática da encenação se alinha à peça representada no ano anterior. Assim, Vasco da Gama (1813) e Pedro Grande (1814) não somente corroboram o caráter doutrinador desempenhado pelo teatro, mas também sustentam o mito narrativo em torno dos viajantes que se aventuravam em terras distantes (presente em nossa história desde as cartas relatorias do "achamento", em 1500). O próprio redator indica que a peça se encaixava perfeitamente na ocasião não somente pelo título, mas pela "natureza do enredo", destinada a "representar aquele Modelo dos Soberanos viajando pelos Reinos estranhos para aprender as Artes que geram comodidade e a riqueza" e "promover a prosperidade da Nação". É uma reiteração do pretenso papel de Portugal diante da colônia: descortinar, simbólica e praticamente, o "mundo civilizado" nas ainda inóspitas paragens do Brasil, discurso completamente alinhado ao que escreve Pero Vaz de Caminha em sua Carta relatoria de 1500.

9 No ano seguinte, o periódico novamente menciona a celebração: "A 12 do corrente celebrou-se o Natalício de S.A.R o Sereníssimo Príncipe da Beira, com a pompa do estilo” (IDADE D’OURO, 1815). 
${ }^{10}$ No ano seguinte (1820), o aniversário natalício da Rainha instigou um relato semelhante: "RIO DE JANEIRO. Os aplausos ao Felicíssimo Aniversário de SUA MAJESTADE a RAINHA Nossa Senhora, referidos na Gazeta precedente, foram continuados no Real Theatro de S. João, que EL-REI Nosso Senhor Se Dignou de Honrar com a Sua Augusta Presença. Pelas 8 horas da noite, SUA MAJESTADE, Acompanhado da Sua Real Família, Se transportou em grande estado ao mencionado Theatro, que se achava iluminado com profusão e elegância. Ao chegar EL-REI Nosso Senhor à Real Tribuna, romperam os espectadores em repetidos Vivas à Sagrada Pessoa de SUA MAJESTADE e à Sua Real Família, e a música tocou o hino nacional. Seguiu-se a representação da excelente Ópera Séria intitulada a Vestal, música do célebre Puccita. No intervalo do $1^{\circ}$ ao $2^{\circ}$ Ato se executou o novo Baile, Acís e Galatéa. O respeito e a satisfação que se divisava nos semblantes de todos os espectadores eram correspondidos pela Afabilidade de SS. MM. e AA. RR” (GAZETA DO RIO DE JANEIRO, 1820a, grifo nosso). Observe-se que as referências ao Rei são aludidas com iniciais maiúsculas e os tratamentos pronominais conferidos aos "sagrados" membros da realeza são os mesmos dedicados às máximas divindades católicas: "Nosso Senhor" e "Nossa Senhora".

11 O autor acrescenta: "Quando o Rio de Janeiro volta a ter uma temporada operística em 1843, o gosto havia mudado. Novos paradigmas guiavam o ensino da música e a profissionalização do artista. Havia um conservatório funcionando de acordo com modelos europeus, grandes teatros de ópera já existiam em algumas capitais e o Rio de Janeiro começa a fazer parte do roteiro internacional de solistas e companhias líricas. Mas, a despeito dessa mudança toda, a ópera ainda era um espetáculo político, e não tardaria muito até que aparecessem compositores sintonizados com as políticas ao mesmo tempo modernizantes e nacionalistas do novo governo e que se envolvessem no projeto de criação de uma ópera nacional - mas não excessivamente nacional - explorando temas históricos e nativistas sobre as bases sólidas do bel canto italiano e da grand opéra francesa. Tudo isso, é claro, com o apoio nada desinteressado do novo imperador" (BUDASZ, 2008, p. 182-183).

12 “Adverte-se ao respeitável público que hoje Quarta feira 13 do corrente mês de Setembro, no Real Theatro de $S$. João, se representa pela primeira vez a Ópera anunciada do insigne Rossini, intitulada: A Cenerentola ou o triunfo da virtude" (GAZETA DO RIO DE JANEIRO, 1820b).

${ }^{13}$ Comentando esta passagem, Mariz pontua: “[...] um verdadeiro acontecimento musical: a première de Don Giovanni, de Mozart, em benefício de Paulo Rosquellas no papel título e com a participação de Maria Teresa Fasciotti. Era comum na época fazer espetáculos em benefício dos melhores artistas. Essa ópera foi estreada em 1789 em Viena” (2008, p. 46).

\section{Referências}

BUDASZ, Rogério. Teatro e música na América portuguesa: convenções, repertório, raça, gênero e poder. Curitiba: DeArtes/ UFPR, 2008. 290p.

MARIZ, Vasco. A música no Rio de Janeiro no tempo de D. João VI. Rio de Janeiro: Casa da Palavra, 2008. 109p.

PACHECO, Alberto José Vieira. Cantoria joanina: a prática vocal carioca sob influência da corte de D. João VI, castrati e outros virtuoses. Tese de Doutorado. Instituto de Artes da Universidade de Campinas, 2007. Campinas: UNICAMP, 2007. 359p.

SCHERPEREEL, Joseph. A orquestra e os instrumentistas da Real Câmara de Lisboa de 1764 a 1834. Lisboa: Fundação Calouste Gulbenkian, 1985. 357p.

TEIXEIRA, Ivan. Mecenato pombalino e poesia neoclássica: Basílio da Gama e a poética do encômio. São Paulo: EDUSP/ FAPESP, 1999. 620p.

\section{Periódicos}

CORREIO BRAZILIENSE, Londres, 01 jun. 1808. p. 78-79.

, Londres, 23 abril 1810, p. 420.

GAZETA DO RIO DE JANEIRO, Rio de Janeiro, 22 jul. 1809. p. 7-8.

_, Rio de Janeiro, 16 out. 1813. p. 3-4.

, Rio de Janeiro, 18 jan. 1814. p. 4.

, Avisos, Rio de Janeiro, 15 maio. 1816a. p. 4.

, Rio de Janeiro, 17 fev. 1816b. p. 2-3. 
_, Rio de Janeiro, 25 out. 1817. p. 4.

Rio de Janeiro, 23 jan. 1819. p. 1.

, Rio de Janeiro, 27 abr. 1820a. p. 1.

, Rio de Janeiro, 13 set. 1820b. p. 4.

, Rio de Janeiro, 08 set. 1821a. p. 4.

, Rio de Janeiro, 02 out. 1821b. p. 4.

, Rio de Janeiro, 08 nov. 1821c. p. 6.

, Rio de Janeiro, 08 dez. 1821d. p. 4.

, Rio de Janeiro, 18 set. 1821e. p. 5-6.

, Rio de Janeiro, 17 jan. 1822a. p. 4.

, Rio de Janeiro, 23 nov. 1822b. p. 4-6.

Rio de Janeiro, 19 nov. 1822c. p. 1-5.

IDADE D’OURO, Bahia, 13 dez. 1811a. p. 4.

, Bahia, 20 dez. 1811b. p. 3-4.

, Bahia, 24 jan. 1812a. p. 3.

, Bahia, 24 jan. 1812b. p. 4.

, Bahia, 31 jan. 1812c. p. 3.

, Bahia, 05 fev. 1812d. p. 1-2.

, Bahia, 02 jun. 1812e. p. 4.

Bahia, 13 out. 1813. Suplemento, p. 6-8.

, Bahia, 29 mar. 1814a, p. 5-7.

, Bahia, 07 out. 1814b, p. 4.

, Bahia, 14 out. 1814c, p. 1.

, Bahia, 17 out. 1815, p. 1.

, Bahia, 30 jan. 1816, p. 5.

, Rio de Janeiro, 03 mai. 1819, p. 1.

Humberto Amorim - Professor da Universidade Federal do Rio de Janeiro (UFRJ) desde 2007. Doutor em Musicologia (UNIRIO), mestre em Práticas Interpretativas (UNIRIO), possui ainda três graduações na área musical, além de ter obtido o Máster em violão clássico pela Universidad de Alicante (UA), Espanha. Já realizou concertos, palestras e lançamentos em 13 países e publicou um DVD e dois livros pela Academia Brasileira de Música: Tacuchian por Humberto Amorim (2015), Ricardo Tacuchian e o Violão (2014) e Heitor Villa-Lobos e o Violão (2009), este último considerado pela crítica "a maior pesquisa já realizada sobre o assunto no Brasil" (Revista Violão Pro, 2009), "um estudo minucioso" (Revista Concerto, 2010) e "leitura obrigatória para quem quiser entender a obra do compositor para o instrumento" (Jornal da AV-Rio, 2010). Desde 2016, vem publicando uma série de artigos em revistas especializadas e anais de eventos científicos, resultados de seu período como pesquisador-residente (2015-2017) na Fundação Biblioteca Nacional (FBN). 